Vol. 3, No. 1, pp. 33-44, 2022

\title{
The Possible Regulation Model to Optimize the Automatic Exchange of Information (AEOI) In Indonesia Through Directorate General of Taxation, Ministry of Finance and Financial Services Authority
}

\author{
Tivana Arbiani Candini*, Putri Purbasari Raharningtyas Marditia, Kelly Kwannaka, Jeanny Liany \\ Faculty of Law, Atma Jaya Catholic University, Jakarta, Indonesia \\ *Corresponding author email: tivanacandini@gmail.com
}

\begin{abstract}
Tax Treaty is a bilateral(two-party) agreement made by two or more than two countries to resolve some issues involving double taxation, transfer pricing, and treaty shopping. Several governments and organizations use model treaties generally as starting points, such as OECD Model Convention and US Model Convention. As a member of G20, Indonesia has participated in The Automatic Exchange of Information (AEoI) provides for the automatic exchange of predefined set of financial accounts information between tax authorities, based on The Common Reporting Standard (CRS), as also mentioned in Tax Information Exchange Agreement (TIEA) implemented in 2018. In order to implement AEoI the Indonesian regulator needs to review the Banking Law and the Tax Provisions and Procedures, there is an urgent need to regulate a regulation as a standard that will be used in CSR, support the tax reform and to enhance the capacity and the authority of Directorate General of Taxation, Ministry of Finance and Financial Services Authority, while still considering the protection for the Bank Secrecy. The method used in this paper is normative legal research, including comparative law research among regulations in Indonesia, Singapore and Malaysia. This research will formulate a model regulation that can facilitate the implementation of the AEoI to harmonize the protection of Tax Evasion and Bank Secrecy in Indonesia.
\end{abstract}

Keywords: Regulation Model, The Automatic Exchange of Information (AEOI),Tax Treaty, Bank Secrecy, Tax Evasion

\section{Introduction}

As the world becomes increasingly globalized and cross-border business activities become the new norm, tax administrations need to work together to ensure that taxpayers pay the right amount of tax to the right jurisdiction (Subroto, 2020). The urgent effort in order to make tax administrations ready for facing the challenges of the fight against tax evasion, while embracing Industry 4.0, is to provide them with the necessary legal, administrative and IT tools for verifying compliance of their taxpayers. Furthermore, the enhanced cooperation between tax authorities through AEoI is crucial in forming national tax administration in line with the globalised economy (Krustiyati and Hugeng, 2019). Globalisation is one of mankind's greatest achievements, with the existence of globalisation everything that seems so far can be reached easily. A lot of things have changed due to globalization, some of them are positive and some are negative. One of the biggest impacts we can see from globalisation is taxation. If we see it from the positive side, paying taxes has become easier with the help of technology, but if we see it from the negative side it is also easier for taxpayers to avoid paying their tax. The problem has been laid due to difficulty in accessing tax from across borders, and this has given people a chance to avoid paying taxes, by transferring or manipulating assets and/or wealth to other countries (Darmanti and Mangkan, 2020). This practice has caused injustices and inequality to other taxpayers. The tax authorities have already implemented the exchange of information on request; however this method is ineffective to fight against offshore tax evasion. The tax authorities must already obtain the evidence of their suspicion over the taxpayers, otherwise their request may be denied as a "fishing expedition". The demand for offshore financial information is obvious since it will enable tax authorities to oversee the level of offshore tax compliance (Dewi and Cynthia, 2018).

The arising problems has made several governments of the states agree to participate in Automatic Exchange of Information (AEoI) in the G20 Finance Minister and Central Governors Meeting in Germany (Hakelberg, 2015). Indonesia as one of the participants in this meeting has firmly stated it's readiness to work together and achieve AEoI 
with other members of G20, with the hope that this collaboration can close the loophole that exists in the Indonesian tax system and refurbished financial information management system in Indonesia (Tedja et al., 2019). The Directorate General of Taxation has stated that Indonesia has partnered with 98 countries, including tax havens countries like Hong Kong, Singapore and Panama. The 98 countries were on the latest update to the list of countries that had provided their tax data to Indonesia, while Indonesia had provided its tax data to 82 countries in 2019. The goal was to expand the number of countries reporting to Indonesia, while the Indonesian Government would use the tax data from other countries to track down any Indonesian citizens with unpaid taxes. The two new Directorates for taxation data and for information communication technology should have optimized the use of the data. However not all the data from other countries could be used to track unpaid taxes, since some of the data was rejected because they do not meet the data standard referring to the Common Reporting Standard (CRS) for the AeoI (Rahimi-Laridjani and Hauser, 2016).

The Automatic Exchange of Information (AEoI) is a tax standard that governs how tax authorities of participating countries exchange information related to financial accounts held by taxpayers outside their jurisdiction of tax residence, based on The Common Reporting Standard (CRS), as mentioned in Tax Information Exchange Agreement (TIEA) in 2018 (Lesage et al., 2020). The AEoI is supposed to accommodate the automatic exchange of information between countries without having to request it. The Common Reporting Standard (CRS) is an information standard for the AEOI regarding financial accounts on a global level, between tax authorities, approved and published by the Organisation for Economic Co-operation and Development (OECD) in 2014. The existence of AEOI and CRS have a specific purpose to ensure tax transparency between committed countries and further goal is to reduce global tax evasion and transfer pricing. The effective collaboration between tax authorities will optimize financial tax policies for now and in the future (Finér and Tokola, 2017).

OECD has released around 100 countries, of which 55 of them stated their full commitment to participate in the AEoI program (Falk, 2006). The initiation was started by the United States of America by publishing Foreign Account Tax Compliance ACT (FATCA), which produced an obligation for Financial Institutions which are located outside the USA to submit the Financial Account Report owned by citizens of the USA to the Government of the USA (De Simone et al., 2020). Thus, in early 2012, the US, along with the five European nations, committed to an intergovernmental approach to FATCA, resulting in two variants of IGAs. Under Model 1, foreign financial institutions would give the required information to their domestic fiscal authorities who would report them to US authorities, while under Model 2, foreign financial institutions would share information with US authorities directly after establishing account holders' consent. In 2014, the members of G20 Countries and OECD agreed to formulate a policy, similar to FATCA, through the Common Reporting Standard (CRS) as a fundamental standard in globally exchanged information.EU Member States also adopted the policy by publishing the information related to interest payment on savings, employment income, directors fees, income from immovable property and few more during 2015-2018, followed by Tax Ruling and Financial Account in 2018 and 2019 (Petres, 2020).

Indonesia was one of the countries adopting AEoI, together with Australia, Barbados, Brazil, Canada, Chile, China, Colombia, Gibraltar, Greenland, Iceland, Japan, Mauritius, Malaysia, New Zealand, Panama, Pakistan, Russia, Saudi Arabia, Singapore and Uruguay in 2018 (G20 Countries). All those countries agreed on an agreement which is called The Convention on Mutual Administrative Assistance in Tax Matters (Ruiz, 2006). It comprises, of a comprehensive framework for Reporting Financial Institutions to review the Financial Accounts they hold, to collect specific information on Financial Accounts held by Reportable Persons, and the Persons (individual or Entity Account Holders, and the individuals that control Entity Account Holders that are Passive Non-Financial Entities) each year and to report it to the tax authorities where the Reporting Financial Institutions are located. The information is then sent by those tax authorities to the tax authorities of its exchange partners where the Reportable Persons are resident for tax purposes. It can then be used by the receiving tax authorities to help ensure compliance by their taxpayers (Dombrowski, 2017).

In Indonesia, there are three finance institutions that manage finance sectors, namely Bank, Non-Bank Financial Institution and Capital Market (Rahmayati, 2021). The most vital one is the Bank, since it strongly requires a high level of trust from the public. As a fiduciary institution, the Bank needs to protect the customers with Bank Secrecy, as one of the requirements that need to be fulfilled, which is stipulated in Law No.7 of 1992 and the Law No. of 1998. The relation between Bank and Bank Customer is not just limited to contractual relations, but there is an obligation to disclose information regarding the customer, unless it is subject to be excluded according to the Banking Regulation. The purpose of the AEoI is to provide a Comprehensive Report of the customer data of persons who put their money in foreign banks in order to determine the right amount of tax-related fees that must be paid and the right tax jurisdiction (Hasim et al., 2018)

Facing the challenges of adopting the AEoI Program must be supported by regulations that can harmonize the Bank Secrecy and Taxation Policy, as both are very related and highly significant for equipping business attachment, especially cross-border business attachments between Indonesia and other countries. This article is made to analyze the possible regulation in Indonesia concerning Tax and Bank Secrecy that will optimize the implementation of the Automatic Exchange of Information (AEoI). In order to obstruct the analysis, we also exercise the policy in Singapore and Malaysia as ASEAN countries that also apply AEoI, as a comparison (Subagyono et al., 2019). 


\section{Methodology}

The method used in this research is normative legal research, as a study of documents, utilizes qualitative method in analyzing data and using secondary data as the source, such as regulation, text books, legal theories, doctrines, reports and journals to produce argumentation, a theory or or a legal concept as a prescription in solving a legal problem. This research adopts comparative law research between regulation in Indonesia, Malaysia and Singapore, and legal research on the synchronization of regulation that will give recommendations for possible amendments to the current regulations related to the implementation of the Automatic Exchange of Information (AEoI) concerning Banking Law and Tax Law in Indonesia.

\section{Results and Discussion}

\subsection{The Background Policy in Indonesia}

Indonesia has a "self- assessment" system as the tax collection system. Self-assessment is basically a system that puts taxpayers in full responsibility in counting how much tax they owe. The legal basis for self-assessment is regulated in Article 12 paragraph (1) of the KUP Law which stated "Every taxpayer is obliged to pay the tax they owe in accordance with the provisions of the tax laws and regulations, without relying on the existence of a tax assessment letter." It means that everyone is in charge of their own tax. Using this system as a payment system can bring advantages as well as disadvantages. The advantages of using the system is taxpayers are entrusted by the government to calculate, pay, and self-report their tax in accordance with the applicable tax provisions, while the disadvantages of using this system is taxpayers who have lack of awareness about taxes will not pay their taxes, and this most likely will result in tax resistance. The need to tackle some possible resistance, may need some measures to broaden the tax base including to bring more of the self-employed into the tax system, subjecting employer-provided fringe benefits and all allowances to personal income taxations and reducing the exemptions from value-added taxes. Indonesia has come a long way in improving the tax system over the last decade, both in terms of revenues raised and administrative efficiency (Pratama, 2018).

Discussing further about tax resistance, it comes in two types; active tax resistance and passive resistance. Active tax resistance is a resistance in paying taxes that comes from the initiative of the taxpayer himself. This kind of resistance is chosen in order to avoid or reduce tax obligations that should be paid. More on active tax resistance, it can be categorized in 3 ways (Irianto et al., 2017):

- Tax Avoidance, is a transaction scheme that minimizes the tax burden by exploiting weaknesses in a country's tax provisions. Although it does not directly violate the rules, this action is clearly detrimental to the country.

- Tax Evasion, is a scheme to reduce taxes owed by illegally violating tax provisions. This resistance has the same purpose as tax avoidance but the way they did it is actually violating the rules.

- Tax Delinquency, meaning that the taxpayers refuse to pay taxes the way they should, this taxpayer neglects his obligations, for example, does not submit his tax return on time, and does not pay taxes on time.

Meanwhile, passive tax resistance is the opposite of active tax resistance, in this type the taxpayer does not have any initiative to resist in paying taxes by consent, the resistance comes fully from the surrounding of the taxpayers like the economic structures, social community system, ineffective tax collection system, and several conditions more. The Indonesian Authorities have formulated ambitious development targets, especially for enhancing the nation's infrastructure and expanding the social safety net, which surely imply significant financing needs. In order to meet this objective, it will need more public revenues, and this will be one of the principal challenges for the tax system in the years to come.

To decide which country has the right to receive tax payment from the taxpayers, in Indonesia, we use the Principle of Domicile, Principle of Origin, and Principle of Nationality. Principle of Domicile means Tax collection is imposed on each taxpayer according to their respective domicile. The Principle of Domicile applies to every citizen who stays in that respective country. It does not matter where the income comes from, either from outside of within the country. The domicile principle also applies to individuals and institutions, both local and foreign, who reside in Indonesia and are required to pay taxes to the Indonesian government. Principle of Origin means the treatment of tax collection is adjusted to the country where your source of income is derived. Last, the Principle of Nationality means the obligation of every citizen to continue to deposit taxes to the state even though they are working and/or living abroad..

Facing the somewhat challenging application of those principles in many different countries, there is a need for a tax treaty. Tax treaty is an International multilateral or bilateral agreement that is made by two countries or more. This treaty is intended to determine the allocation of taxation rights from a transaction that occurs between the source country and the country of domicile. The main aim of the tax treaty is to avoid double taxation that will burden businesses, increase foreign investment, increase human resources, exchange information to prevent tax evasion, and equalize status between countries. Indonesia has 70 state partners that are committed to the Tax Treaty concerning Double Taxation. To conclude the Tax Treaty, it needs Mutual Agreement Procedure (MAP) between Tax Authorities of the committing States. 
The other related issue is Bank Secrecy, which unfortunately will be affected by the disclosure of information of financial accounts. In Indonesia bank secrecy is regulated in the Indonesia Banking Law, which simply defines bank secrecy as everything related to information about customer's savings. Each Indonesian bank is bound by this law to protect the information and data of their customers, and needless to say for a bank to gain trust from the customer, the ability from a bank to keep tight the confidentials information of their customer is highly crucial. The fundamental base of banking activity is trust between the customer and receiver Bank. Nevertheless, some exceptions are given in terms of bank secrecy, and one of those was for tax purposes. Explained in Chapter 41 of Indonesia Banking Law that for tax purposes, the Head of Bank Indonesia (by request of the Ministry of Finance) will be authorized to issue a written order for the bank to show information and reveal written evidence as well as letters regarding a customer's financial condition to tax officials.

The relative theory of bank secrecy is the one being used in Indonesia, where the bank is obliged to maintain the secrecy of its customer, but not absolute. In other words, the bank is still allowed to open the secrets of its customers in certain circumstances, such as if there is urgent need, public interest or other matters by the rules. Distinguishing it with the absolute theory in which bank secrecy is a rigid regulations that might not be revealed in regardless of any situation, the relative theory of bank secrecy is defined that bank secrecy is to be followed by regulations, but through a situation such as suspicion of illegal tax activity, bank secrecy could be exempted in this case.

There are exceptions to bank secrecy provisions according to Law Number 7 of 1992 in conjunction with Law Number 10 of 1998, namely;

1. For tax purposes;

2. For settlement of bank receivables that have been submitted to the State Agency for Receivables and Auctions;

3. For the sake of justice in criminal case;

4. In a civil case between the bank and the customer;

5. In exchanging interbank information;

6. Upon request, approval from the Power of Attorney from the customer or his heir.

There are also another exception besides those above provisions, whis is the exception governed by the Supreme Court Letter No.KMA/694/R45/XII/2004 concerning legal consideration for the implementation of the authority of the Corruption Eradication Commission, in response to the Letter of Governor of Bank Indonesia No.6/2/GBI/DHK/Secrecy that gives authority to the Corruption Eradication Commission in implementing investigation and prosecution assignments. Based on these provisions, the permit procedures for disclosure of Bank Secrecy, as stipulated in Article 29 Paragraph 2 and 3 of Act Number 20 of 2001.

\subsection{Tax Regulation and Bank Secrecy Regulation Concerning the Implementation of AEoI in Indonesia}

\subsubsection{Tax Regulation}

In implementing the AEoI, Indonesia needed to replace or add several regulations in taxation, to guarantee the effectiveness of the new policy. Law No 19/2000 concerning Tax Collection with a Warrant, has not ruled on the mechanism of tax claim that involves State Partners Authorities. Indonesian still depended on the Tax Treaty, which facilitated State partners to be in charge of tax collection at their territory upon request. The integrated data system to detect the concrete income of the taxpayers is urgently needed. To be in line with the need of exchanging information between State partners, the Ministry of Finance (MoF) issued MoF Regulation No.60/PMK.03/2014, as amended by MoF Regulation No. 125/PMK.010/2015 concerning Exchange of Information.

The other regulation is the Law No. 9/2017 concerning Stipulation of Government Regulation in Lieu of Law No. 1/2017 concerning Access to Financial Information for Tax Purposes. With these regulations, the government can access all financial information from a person for tax purposes and for the implementation of international agreements in taxation or Automatic Exchange of Information (AEoI). This information then will be sent to the origin country, and will be used by them to collect tax. Another regulation is the Minister of Finance is Regulation Number 19/PMK.03/2018 concerning Procedures for Exchange of Information based on International Agreements. With these regulations, the Indonesian government is supposed to easily ask other country members about tax data they need, such as income tax withholding data, account data, country-by-country reports, and other information based on the agreement that they agree to. This information will be used by the government to analyse taxpayer assets and/or wealth.

Furthermore, in order to support the implementation of AEoI, Indonesia's government has also ratified the Tax Information Exchange Agreement, Convention On Mutual Administrative Assistance In Tax Matters, and published the Presidential Regulation No. 159/2014 concerning ratification of Convention On Mutual Administrative Assistance In Tax Matters and PMK-39/PMK.03/2017 concerning the Procedure of Exchanged Information Based on Treaty. The convention is needed as a basis for tax law enforcement, expansion of access to information in the field of 
taxation, implementation of tax collection assistance, and cooperation in joint administrative assistance with other countries.

\subsubsection{Bank Secrecy Regulation}

As a result of agreement between G20 member countries with the Organisation for Economic Cooperation and Development (OECD), a global policy called The Automatic Exchange of Information (AEoI) then became an important element in the Common Reporting Standard (CRS) (Wijayanti, 2019). Despite the many advantages of AEoI such as: reducing the potential of tax evasion, increasing the tax ratio, encouraging tax compliance, increasing transparency, cooperation, as well as accountability between tax institutions, and tracing the track record of taxpayers despite being in another country. However, the need for the protection of the bank customer privacy leads to another challenge, that should be also considered to preserve the Banks from lack of investments (Setiawan, 2020).

Various laws and regulations had been set in order to prepare Indonesia for Automatic Exchange of Information, including Government Regulation in Lieu of Law No. 1 of 2017 and Law No. 9 of 2017. Within 3 years of implementing AEoI since 2018, the Government has received more than 1,6 million of financial information worth more than 246,7 billion Euros from exchange of financial information for tax purposes. The Automatic Exchange of Information (AEoI) practice itself requires a bank institution to provide government confidential data of their customers which were suspected of illegal tax activity. On the other side, is the obligation of a bank institution to ensure the confidentiality of customer's data, in order to avoid unauthorized disclosure to certain parties (such as business competitors) which might result in threat to the public. But in the case of suspicion of illegal tax activity, the bank's secrecy somehow prevents authorities from detecting the breach conducted by customers.

Provision of bank secrecy in Indonesia could not be defined as rigid regulations, as this provision could be waived when the public interest is deemed to be harmed by certain individuals. It is undeniable that even though bank secrecy is a fundamental aspect needed to be followed by a banking institution, public interest should be put on top priority as it is crucial to be protected. A banking institution is not an institution for abuse of power or a place for lawbreakers to cooperate and work together, taking profit through unreasonable ways.

Hence, the Indonesian Government created Law No. 9 of 2017 to accommodate this act, to permit authorities in accessing financial information for tax purposes. The Multilateral Competent Authority Agreement which was obligated to be signed by member countries as a form of commitment on these cooperation marks the end of the bank secrecy era in Indonesia, it has also broadly opened Indonesia's Government access to every financial information of Indonesian customers with an international financial account through AEoI. Practically, AEoI settings in Indonesia are through a synchronized system which enables countries to automatically trace each taxpayer that creates a banking account in another country. This practice makes it easier for countries to trace where their citizens put their assets, in case a transfer pricing or even money laundering practice occurs (Huang, 2018).

Since AEoI itself is not reliable enough to reveal information regarding beneficial owners, the beneficial owners in this case refer to those who have gained revenue and have full control in regards to the tax activity. In the context of Country by Country Reporting (CbCR), for instance, it only refers to customers-related information strictly to their revenue and total account balance. Hence, aside from AEoI, Exchange of Information on Request (EoIR) is equally important. EoIR plays a big role in exploring beneficial ownership, it works when a country requesting the financial information of their citizen to another country where this citizen stores their financial assets, these are usually based on the suspicion that their citizen are doing tax avoidance activity, tax evasion, abuse on tax treaty with certain way or scheme, and tax obligations that were not fulfilled yet. In this case, the citizen whose data is requested must be under supervision of tax compliance, development and analysis of information, data, reports and complaints, examination, collection, examination of preliminary evidence, investigation of criminal acts in the taxation sector.

Following Indonesia's signing of the Convention on Mutual Administrative Assistance in Tax Matters (MCAA) on the automatic exchange of financial account information (AEOI) in 2011, the country is expected to undertake the first information exchange by September 2018. As a consequence, the Indonesian tax authority will receive taxation information of Indonesian citizens who have placed their assets in the partner countries/signatory countries to the MCAA, and vice versa. The AEOI is anticipated to persuade Indonesian citizens to repatriate their assets.In preparation for 2018, the Indonesian government has developed and enacted several domestic regulations. The Ministry of Finance (MoF) issued MoF Regulation No. 60/PMK.03/2014, as amended by No. 125/PMK.010/2015, concerning procedures of exchange of information, which stipulates general matters relating to the AEOI, including the types of exchange of information. Separately, the Financial Services Authority (locally known as Otoritas Jasa Keuangan, or OJK) issued OJK Regulation No. 25/POJK.03/2015 concerning the submission of information on foreign customers relating to taxation to partner countries or partner jurisdictions (OJK Regulation No. 25/2015), which requires financial institutions to submit reports of taxation information of foreign banking customers to the Indonesian tax authority. To this date, several financial institutions have started implementing these rules in relation to their customers.

To further implement the AEOI and the OJK Regulation No. 25/2015, a Government Regulation in Lieu of Law (Peraturan Pemerintah Pengganti Undang-undang) and an OJK circular letter are being prepared. The OJK circular 
letter will regulate the procedures of due diligence of foreign banking customers and is likely to be issued in April 2017. In addition, an electronic system application known as the "Disclosure of Bank Secrecy Request Application" (Aplikasi Usulan Buka Rahasia Bank, or Akasia) has been prepared, which will work with a system application prepared by OJK known as the "Disclosure of Bank Secrecy Application" (Aplikasi Buka Rahasia Bank, or Akrab). OJK has also prepared a reporting system called the "Foreign Customer Submission System" (Sistem Pelaporan Nasabah Asing, or SiPINA). Collectively, these systems will coordinate data disclosure requests and reporting between the Indonesian tax authority, the MoF, and the OJK. With all these preparations, Indonesia intends to be fully prepared and to comply with all requirements of the AEOI, so that all partner countries/signatory countries to the MCAA will be willing to cooperate with Indonesia. This includes Singapore, which has previously refused to exchange financial information with Indonesia.

\subsection{The Policy in Other States (Malaysia and Singapore)}

\subsubsection{Tax Policy}

Since 2017 to 2018 there have been many countries that implement AEoI to their domain, by carrying out the ideology of information disclosure for tax they have the same hope that AEoI can increase the potential of state tax revenues to support national development programs. Some of the countries that are listed are Indonesia, Singapore, and Malaysia. In order to implement AEoI, requirements are also needed, and one of them is by adding Law supporting information disclosure. We can find in the table below variables that can indicate some similarities and differences among Indonesia, Malaysia and Singapore Tax Regulation after implementing the AEoI.

Looking at the Table 1, we can see that Indonesia, Singapore, and also Malaysia have replaced and/or added new regulations in order to implement AEoI in their country. Since the implementation, there has been an increase in tax revenue in general. We probably can assume that AEoI has in a way warned people to be more aware of their tax obligations, and start paying their taxes the way they should have. From the implementation of AEoI, all three of the states have also gained financial data and have done some exchanges with other countries. In General, AEoI implementation does not stop tax evasion completely, it can only prevent it to some extent, especially with these three country tax payment systems which are self assessment. The added regulations to implement AEoI arranged by the three countries regarding tax evasion have the aim that tax evasion can be prevented and decreased, even though it needs much more effort to totally diminish tax evasion .

Indonesia regulation regarding tax evasion is written in KUP article 38 and article 39, it was written that everyone that intentionally or unintentionally not paying their taxes can be punished. Based on article 38 the fine is at least one times the amount of tax that has not been paid and at most two times the amount or sentenced to imprisonment for a minimum of 3 months or a maximum of 1 year, and based on article 39 imprisonment for a minimum of 6 months and a maximum of 6 years and a fine of at least 2 times the amount of unpaid or underpaid tax and a maximum of 4 times the amount of unpaid or underpaid tax payable.

On 9 December 2014, Singapore and the United States signed an intergovernmental agreement to facilitate the implementation of FATCA in Singapore. Singapore has also committed to implementing the Common Reporting Standard ("CRS") by 2018. In January 2016, Singapore ratified the Convention on Mutual Administrative Assistance in Tax Matters, which it had signed in May 2013. The Income Tax Act (Chapter 134) was also amended to incorporate exchange of information provisions. On 14 May 2013, the Ministry of Finance, Monetary Authority of Singapore and the Inland Revenue Authority of Singapore issued a joint statement declaring that Singapore was "significantly strengthening its framework for international cooperation to combat cross-border tax evasion" . They announced four key steps: extending EOI assistance to all existing tax agreement partners, without updating individually bilateral tax agreements; signing the Convention on Mutual Administrative Assistance in Tax Matters; allowing IRAS to obtain bank and trust information from financial institutions without having to seek a court order; and concluding with the United States an Inter-Governmental Agreement that would facilitate the FATCA compliance of financial institutions in Singapore. Singapore doubled the number of jurisdictions it would exchange information with, and conducted a critical review of high tax risk accounts.

In July 2013, serious tax crimes were designated as money-laundering predicate offences, and financial institutions were required to conduct reviews regarding tax Annual Report. The definition of a "foreign serious tax offenses" was also expanded with effect from 1 September 2014 to send a signal that Singapore was not willing to harbour assets connected to foreign tax evasion. Financial institutions are now obliged to file a suspicious transaction report if they have reasonable grounds to suspect that funds represent the proceeds of tax evasion. The regulations about tax evasion are written in Section 96 of the Singapore Income Tax Act, tax evaders will be penalized 300\% of the tax undercharged. They may also be punished by three years of imprisonment, a fine of $\mathbf{S} \$ 10,000$, or both, while tax evasion in Malaysia can be charged under under the Income Tax Act (ITA) 1967 and the Anti-Money Laundering And Anti-Terrorism Financing Act 2001(AMLATFA 2001).

In Malaysia, there are general anti-avoidance provisions (GAAR) as well as specific anti-avoidance provisions (SAAR), the general regulations was written in Section 65 - Settlement, Section 140 - Power to disregard certain transactions, Section 140A - Power to substitute the price and disallowance of interest in certain transactions, and Section 141 - Powers regarding certain transactions by non-residents. The specific regulations was written in Section 
29 - Basis period to which income obtainable on demand is related, Section 32(3)(a) - Ascertainment of value of living accommodation for a director of a controlled company, Section 44(5A) to (5D) - Shareholder continuity rules, and Paragraphs 38 to 40, Schedule 3 and Income Tax rules relating to disposals subject to control. While Singapore and Malaysia have general regulations regarding anti avoidance, Indonesia only has specific anti-avoidance provisions. It was written in Indonesia Income Tax Act section 18, that regulates the power of Directorate General of Taxation to consider whether the transaction has not been conducted at arm's length due to the existence of a " special relationship" between the parties, the consideration paid may be adjusted. The Directorate General of Taxation power extends to all domestic and cross border transactions. In addition to the power of the DGT to adjust transfer prices, there are thin capitalization considerations and controlled foreign company rules, that can be found in the Table 1 .

Table 1. Comparative Tax Policy (Indonesia, Singapore and Malaysia)

\begin{tabular}{|c|c|c|c|}
\hline Variable & Indonesia & Singapore & Malaysia \\
\hline $\begin{array}{c}\text { Regulations } \\
\text { concerning AEoI }\end{array}$ & $\begin{array}{l}\text { 1. Enacted Law } \\
\text { Number } 9 \text { of } 2017 \\
\text { on Enactment } \\
\text { ofGovernment } \\
\text { Regulation in Lieu } \\
\text { of Law of The } \\
\text { Republic of } \\
\text { Indonesia, Number } 1 \\
\text { of } 2017 \text { on Access to } \\
\text { Financial } \\
\text { Information for Tax } \\
\text { Purposes to Become } \\
\text { Law } \\
\text { 2. Introduced } \\
\text { Regulation of the } \\
\text { Minister of Finance } \\
\text { Number } \\
\text { 19/PMK.03/2018 on } \\
\text { Technical Guidance } \\
\text { on Access to } \\
\text { Financial } \\
\text { Information for Tax } \\
\text { Purposes. } \\
\text { 3. Law No.28/2007 } \\
\text { concerning general } \\
\text { provisions and } \\
\text { taxation procedures. }\end{array}$ & $\begin{array}{l}\text { 1. Enacted Part XXB of } \\
\text { the Income Tax Act; } \\
\text { 2. Introduced the } \\
\text { Income Tax } \\
\text { (International Tax } \\
\text { Compliance } \\
\text { Agreements) } \\
\text { (Common Reporting } \\
\text { Standard) } \\
\text { Regulations 2016. }\end{array}$ & $\begin{array}{l}\text { 1. Enacted Sections } \\
\text { 113A, 119B, 132B } \\
\text { and 154(1)(c) of the } \\
\text { Income Tax Act } \\
1967 ; \\
\text { 2. Introduced the } \\
\text { Income Tax } \\
\text { (Automatic } \\
\text { Exchange of } \\
\text { Financial Account } \\
\text { Information) Rules } \\
\text { 2016 - P.U.(A) } \\
\text { 355/2016 as } \\
\text { amended in } 2017 \\
\text { and 2020; } \\
\text { 3.troduced the } \\
\text { Labuan Business } \\
\text { Activity Tax } \\
\text { (Automatic } \\
\text { Exchange of } \\
\text { Financial Account } \\
\text { Information) } \\
\text { Regulations } 2018- \\
\text { P.U.(A) 20/2018 } \\
\text { (with effect from } 1 \\
\text { July 2017) as } \\
\text { amended in } 2020 .\end{array}$ \\
\hline $\begin{array}{l}\text { Tax Collection } \\
\text { System }\end{array}$ & $\begin{array}{c}\text { Self } \\
\text { Assessment }\end{array}$ & $\begin{array}{c}\text { Self } \\
\text { Asessment }\end{array}$ & $\begin{array}{c}\text { Self } \\
\text { Asessment }\end{array}$ \\
\hline $\begin{array}{l}\text { Object of the } \\
\text { Regulations }\end{array}$ & $\begin{array}{l}\text { Tax Informations } \\
\text { and tax access }\end{array}$ & $\begin{array}{l}\text { Tax Informations } \\
\text { and tax access }\end{array}$ & $\begin{array}{l}\text { Tax Informations } \\
\text { and tax access }\end{array}$ \\
\hline $\begin{array}{l}\text { Subject of the } \\
\text { Regulations }\end{array}$ & Taxpayers & Taxpayers & Taxpayers \\
\hline Authority & $\begin{array}{c}\text { Directorate General } \\
\text { of Taxes. }\end{array}$ & $\begin{array}{l}\text { The Inland Revenue } \\
\text { Authority of Singapore }\end{array}$ & $\begin{array}{c}\text { Inland Revenue Board } \\
\text { of Malaysia }\end{array}$ \\
\hline $\begin{array}{l}\text { Tax Avoidance } \\
\text { Rules }\end{array}$ & $\begin{array}{l}\text { SAAR (Spesific Anti- } \\
\text { Avoidance Rules) }\end{array}$ & $\begin{array}{l}\text { GARR (General Anti- } \\
\text { Avoidance Rules) }\end{array}$ & SAAR and GAAR \\
\hline Tax Treaty & with 67 jurisdictions & with 100 jurisdictions & with 94 jurisdictions \\
\hline
\end{tabular}


Indonesia also has the least amount of Tax Treaty with other states, compared with Singapore and Malaysia. The Tax Treaties signed by those three, are mostly focused on the double taxation avoidance rather than accommodating exchange information of the taxpayers; therefore, not enough to support the implementation of AEoI.

\subsubsection{Bank Secrecy Policy}

The term often used interchangeably with bank secrecy is financial privacy, a condition in which any transactions between banks and their clients remain undisclosed and secured. There are some adjustments in banking regulations made specifically to implement the AEoI that can be found in the Table 2 .

Table 2. Comparative Bank Secrecy Policy (Indonesia, Singapore, Malaysia)

\begin{tabular}{|c|c|c|c|}
\hline Variable & Indonesia & Singapore & Malaysia \\
\hline Characteristics & Relative & Absolute & Absolute \\
\hline Regulations & $\begin{array}{l}\text { Law Number } 9 \text { of } 2017 \\
\text { on Enactment of } \\
\text { Government Regulation } \\
\text { in Lieu of Law of The } \\
\text { Republic of Indonesia, } \\
\text { Number } 1 \text { of } 2017 \text { on } \\
\text { Access to Financial } \\
\text { Information for Tax } \\
\text { Purposes to Become } \\
\text { Law. }\end{array}$ & $\begin{array}{l}\text { Section } 47 \text { Banking } \\
\text { Act }\end{array}$ & $\begin{array}{l}\text { Section } 133 \text { of } \\
\text { Financial Services } \\
\text { Act. } \\
\text { Income Tax } \\
\text { (Automatic Exchange } \\
\text { of Financial Account } \\
\text { Information) Rules } \\
2016 \text { (AEOI Rules). }\end{array}$ \\
\hline $\begin{array}{l}\text { Object of } \\
\text { Regulations }\end{array}$ & $\begin{array}{l}\text { Giving access to } \\
\text { Authority in terms of } \\
\text { Bank Secrecy }\end{array}$ & $\begin{array}{l}\text { Allow banks in } \\
\text { Singapore to } \\
\text { exchange information } \\
\text { for reasons such as } \\
\text { willful tax evasion }\end{array}$ & $\begin{array}{l}\text { Automatic exchange } \\
\text { of financial } \\
\text { information }\end{array}$ \\
\hline $\begin{array}{l}\text { Subject of } \\
\text { Regulations }\end{array}$ & $\begin{array}{l}\text { Citizens and Bank } \\
\text { Institution }\end{array}$ & $\begin{array}{l}\text { Citizens and Bank } \\
\text { Institution }\end{array}$ & $\begin{array}{l}\text { Citizens and Bank } \\
\text { Institution }\end{array}$ \\
\hline $\begin{array}{l}\text { Exception of } \\
\text { Bank Secrecy }\end{array}$ & $\begin{array}{l}\text { Aside from court orders, } \\
\text { and other exceptions, } \\
\text { Tax purpose is one of the } \\
\text { exceptions of bank } \\
\text { secrecy. }\end{array}$ & $\begin{array}{l}\text { Authority is given } \\
\text { power to obtain } \\
\text { information for tax } \\
\text { related purposes }\end{array}$ & $\begin{array}{l}\text { Aside from court } \\
\text { orders, and other } \\
\text { exceptions, Tax } \\
\text { purpose is one of the } \\
\text { exceptions of bank } \\
\text { secrecy. }\end{array}$ \\
\hline Authority & $\begin{array}{l}\text { Directorate General of } \\
\text { Taxes. }\end{array}$ & $\begin{array}{l}\text { The Inland Revenue } \\
\text { Authority of } \\
\text { Singapore }\end{array}$ & $\begin{array}{l}\text { Inland Revenue } \\
\text { Board of Malaysia }\end{array}$ \\
\hline
\end{tabular}

Alongside Singapore and Malaysia, Indonesia is the first few Southeast Asian countries that has succeeded in implementing Automatic Exchange of Information practice. Meanwhile, one of the neighboring countries, Thailand, was expected to begin in 2022. Between Indonesia, Singapore and Malaysia, Automatic Exchange of Information began in 2018 when Indonesia signed the Multilateral Competent Authority Agreement, taking into account that the MCAA was a multilateral agreement so no bilateral agreement was needed between countries to exchange information.

Between Singapore, Indonesia and Malaysia, all three countries as a matter of fact have exempted tax-related purposes when it comes to revelations of bank secrecy. Each country has their own regulations that result in 
permitting the revelation of bank information. For Malaysia and Indonesia, it was explicitly written in the law and regulations that indeed for tax-related purposes, a revelation is allowed and bank secrecy is made an exception in this case. Aside from tax-related purposes, other causes such as court orders or even death of the customers could be the exception for bank secrecy revelation as well.

Meanwhile in Singapore, though it is not explicitly written for tax purposes, information is allowed to be disclosed for any legal purposes, may be disclosed by court orders or if it is specified in the law. Singapore made substantial amendments to its law in regards to banking secrecy. Bank secrecy regulations in Singapore can be found in Chapter 47 Singapore Bank Law, in which these provisions allow information to be revealed only limited to information about a customer's account with information about the deposit. Singapore has made a clear and complete distinction into Three Schedule of its Bank Law regarding the exceptions to whom this information may be revealed, who were prohibited to spread the information and who were not, unless specified otherwise by law. At common law a contractual duty of confidentiality is implied with respect to the banker-customer relationship. Without a customer's consent, banks incorporated in Singapore or foreign banks with branches in Singapore cannot divulge information relating to the customer's account and transactions to third persons unless there is a court order, a public duty of disclosure or the protection of the bank's own interest requires it. Exceptions to disclosure may be found in the Third Schedule of the Act and include requests for information from a police officer or public officer or a court for the purposes of investigation or prosecution. Singapore is well known as a tax-ruled country in which its citizens pay tax in an orderly manner. Singapore's way to specify its law and regulations in regards to bank secrecy, focusing on the Three Schedules about who may or may not reveal the information, who may or may not receive the information, which information may or may not be revealed, and where other information may be revealed, has shown clear distinctions and truly avoid any hassle in the future in regards to this confidential information to not be misused.

There are two well-known theories in banking access to financial information, the absolute theory and the relative theory. Indonesia adheres to the relative theory, where access to information can be carried out in certain circumstances by parties outside the bank. Singapore and Malaysia adhere to the absolute theory, where the bank has an obligation to keep secrets or statements about its customers that are known to the bank because of their business activities under any circumstances.

The Automatic Exchange of Information was implemented in nearly the same time range for the three neighboring countries, and AEoI itself could reach at least the current objectives, which is to reduce tax evasion, tax avoidance, money laundering, and such practices. Similar to Indonesia which has received more than 1,6 million of financial information worth more than 246,7 billion Euros from exchanging information through AEoI, as of October 2021, Malaysia has resolved more than 4,000 cases involving nearly RM350 million in settlements since AEoI was first implemented.

\section{Analysis of the Policy Recommendation: Theory and Approach for Arrangement of Regulatory Model Development}

\subsection{What Kind of Policy Needed in Indonesia?}

Based on the explanation regarding the landscape of Indonesia regulation on AEOI and bank security conclude that: The purpose of the AEoI to provide a Comprehensive Report of the customer data of persons who put their money in foreign banks in order to determine the right amount of tax-related fees that must be paid and the right jurisdiction may leads to another complication in regulating the Tax Avoidance Rules and the Bank Secrecy.

Tax Treaties between Indonesia and other countries as the tools to avoid double taxation, transfer pricing, tax avoidance and evasion by exchanging information collected by authorities and financial institutions, considered to not provide full implementation to be granted as effective. On the other hand, it might provide more flexibility regarding the exclusion of bank secrecy. The detail and limitation of the relative principle in Bank Secrecy is still needed, to protect the rights of the consumers that have trust relation with the bank.

The idea of anti-avoidance provisions is supposed to prevent taxpayers from entering into transactions that avoid paying tax. There is a generally accepted difference of terms used in the context. The term "avoidance" tends to be used to explain techniques legitimately used to minimize taxation burden whereas the term "evasion" describes deliberate activity, such as increasing allowable deductions, for the purpose of not paying tax.

The author has compared the policy between Indonesia and two other ASEAN countries, which are Singapore and Malaysia in order to pursue a more comprehensive recommendation regarding what kind of policy that is needed in Indonesia to accommodate the Automatic Exchange of Information in line with the Tax and Bank Secrecy Regulation. In general, the research has shown that the limitation and further detail of the relative principle in Bank Secrecy are still needed, to protect the rights of the consumers that have trust relations with the bank. The possible model regulation for the Taxation and Bank Secrecy in Indonesia should seriously consider the implementation of AEoI, Self-Assessment System of the Tax Collection, the Exclusion of Bank Secrecy and the Tax Avoidance Rules along with the review of the Tax Treaty between Indonesia and other countries. 


\subsection{Policy Recommendation}

The approach taken will be through economic analysis of law concepts, an approach which has its base foundation on Utilitarianism. Utilitarianism itself was introduced by Jeremy Bentham, judging whether a behavior is good or not, immoral or not based on the benefit and utilities gained. Consequently, a good regulation based on this economic analysis of law concept, is when a regulation could act as tool or medium to earn and put forth benefits for many parties, in which from the law human as economic creature were originally given chance to decide which field of business that could give them the biggest benefit and guarantee to enjoy the business against other powers. Therefore, based on this approach, law have two roles: (1) Law as tool to earn individual happiness by being the control of necessity between individuals, in order to guarantee the continuity of the implementation of common interests; (2) As the tool to earn individual happiness by being crime deterrent, since the absence of crime will consequence to happiness and advantages of many people. The realization of "Good regulations" by economic analysis of law is the regulations that could give benefits to many individuals and a sense of safety guarantee, which mainly focus on how more parties could get and earn benefits from those regulations, not just definite parties. In this matter, the policy should not only fulfill the need of preventing tax evasion or avoidance, but also need to consider the balance of the importance and the risk of opening information of bank customer's financial accounts.

In practice, for companies, tax levied on income that they received is considered by them as a cost or expense in running a business. Tax expenses will only decrease the profit they get, therefore to minimize it, companies have to make tax planning. By making tax planning many companies aim to be able to pay less tax, but still within the framework of tax regulations. This action can be called tax avoidance. In many countries tax avoidance can be divided as acceptable tax avoidance and unacceptable tax avoidance. The difference between this can be categorized by the ulterior motive of the taxpayers. Until now Indonesia does not have a defined meaning about tax avoidance, acceptable tax avoidance, unacceptable tax avoidance and tax evasion. These things have caused different interpretations between taxpayers and tax authorities, because there is no legal certainty about this matter. From the taxpayers point of view tax avoidance is a legal method that can be done as long as it does not violate the law.

Based on the research results, Indonesian Tax Authority needs to put more attention to the General Anti Avoidance Rule (GAAR) that supposed to be integrated in Income Tax Law, as an anti-avoidance measures, generally statute based, providing criteria of general application, not aimed at specific taxpayers or transactions, to combat perceived tax avoidance. The regulation also needs to provide detailed definitions about legal and illegal tax avoidance, acceptable tax avoidance, unacceptable tax avoidance and tax evasion in order to give legal certainty to the taxpayers and tax authorities. Other than that, there is a need to form a law to implement the Specific Anti Avoidance Rule (SAAR) in Article 18 concerning Income Tax Law (Law No 36 of 2008), which only regulates specific tax avoidance of definite taxpayers, in order to anticipate the potential to "abuse of law". It is expected that the implementation of statutory GAAR can accommodate the limitations of regulators in unpredictable future tax avoidance schemes.

If the approach of economic analysis of law concepts were to be implemented to regulations of model development, then it will be based on the penta-helix approach. Generally, this approach involves five main components in arranging a policy and could be implemented in arranging digital economy policy, as follows: (1) the most affected groups, (2) the main stakeholders, (3) interest groups, (4) advocacy groups, (5) public at large. In the implementation, all components involve public sector, private sector, non-governmental organization, civil citizen, and academics. Several benefits will be obtained with this approach, including:

1. The accumulation of strengths, capacities, and resources from stakeholders to produce policies that can respond appropriately to needs and be implemented;

2. Involving commitment from stakeholders from the beginning so that a sense of belonging to the policies drawn up grows;

3. More reliable implementation due to this commitment; and

4. There is complete input from stakeholders to produce comprehensive considerations for policy formulation.

The main pillar in economic analysis of law concepts to harmonize the AEoI and the Bank Secrecy regulation could be implemented through Non-Cooperative Equilibrium and Efficiency Concepts, by building and strengthening the economic collaboration and strategy that can maximize the profit for the states and community. Related to Tax Regulation, Indonesia should include General Anti Avoidance (GARR), despite only including Specific Anti Avoidance Rules (SAAR), therefore the objectives will be clearly set to classify the tax avoidance and tax evasion based on the effect and the amount of loss of the states. Furthermore, based on that consideration, the Authority can decide whether it is necessary to disclose or exchange the information of financial accounts of taxpayer or other parties who is directly or indirectly involved. On the other hand, the implementation of the AEoI is affected by the Self-Assessment system of the Tax Collection in Indonesia which can potentially facilitate the tax avoidance and tax evasion scheme.

The Tax Treaty, despite the complexity of the ratification and time-consuming process concerning each state, may offer a preventive mechanism of tax avoidance and tax evasion, and gives more legal certainty towards the whole tax issues. Since the Tax Treaty is made to provide the need and the suitable model to the characteristics of each state, it will probably give more guarantee to the Bank Secrecy protection. It is possible to secure financial account 
information that is not related to the tax issues, if it is regulated in detail. Therefore, the trust of bank customers to the bank and furthermore the state will be preserved.

\section{Conclusion}

This paper aims to find the possible model regulation to optimize the implementation of the Automatic Exchange of Information related to Taxation and Bank Secrecy in Indonesia, since the purpose of the AEoI to provide a Comprehensive Report of the customer data of persons who put their money in foreign banks in order to determine the right amount of tax-related fees that must be paid and the right jurisdiction may leads to another complication or contradiction in regulating the Tax Avoidance Rules and the Bank Secrecy. Despite this, it is also important to note that the Indonesian tax authority will only have automatic access to taxation information of foreign citizens. Access to taxation information of Indonesian taxpayers is only available in the event that such taxpayers are undergoing a tax investigation, collection, or objection. The granting of access must also be based on a written request from the Minister of Finance to the Financial Services of Authority. On a separate occasion, the tax authority revealed its plan to revise the controlled foreign companies (CFC) rules by enlarging the definition of a CFC (to capture passive income other than dividends and to lower the ownership percentage in an offshore entity) and include trust structures and indirect control in the revised regulation. It shows that although Indonesia has been practicing the relative principle, the further detail and limitation of the relative principle in Bank Secrecy is still needed, to protect the rights of the consumers, that have trust relation with the bank.

Tax Treaties between Indonesia and other countries as the tools to avoid double taxation, transfer pricing, tax avoidance and evasion by exchanging information collected by authorities and financial institutions, considered to not provide full implementation to be granted as effective. On the other hand, it might provide more flexibility regarding the exclusion of the bank secrecy. Even though, most of the tax Treaties do not include the implementation of AEoI, it can be reviewed to provide the better arrangement for each state. The implementation of AEoI should improve the collaboration between states, balance and harmonize the Tax and Bank Secrecy policy, and not create new problems.

The possible model regulation for the Taxation and Bank Secrecy in Indonesia should consider the implementation of AEoI, Self-Assessment System of the Tax Collection, the Exclusion of Bank Secrecy and the Tax Avoidance Rules along with the approach method taken through economic analysis of law concepts that has its base foundation on Utilitarianism. It should provide more safeguards not just to combat but also to prevent the tax evasion or money laundering, while not diminishing the role of Bank Secrecy as one of the assets of the state that can attract investors.

\section{References}

Darmanti, R. M., \& Mangkan, D. (2020), The Implementation of Automatic Exchange of Information as a Tool to tackle Offshore Tax Evasion : An Experience from Indonesia, Scientax, 2(1) 100-122.

De Simone, L., Lester, R., \& Markle, K. (2020). Transparency and tax evasion: Evidence from the foreign account tax compliance act (FATCA). Journal of Accounting Research, 58(1), 105-153.

Dewi, S. P., \& Cynthia, C. (2018). Aggressiveness tax in indonesia. Jurnal Akuntansi, 22(2), 239-254.

Dombrowski, J. P. (2017). FATCA Compliance: Documentation for an Investment Fund. Journal of Taxation \& Regulation of Financial Institutions, 30(2).

Falk, M. (2006). What drives business Research and Development (R\&D) intensity across Organisation for Economic Cooperation and Development (OECD) countries?. Applied Economics, 38(5), 533-547.

Finér, L., \& Tokola, A. (2017). The Revolution in Automatic Exchange of Information: How Is the Information Used and What Are the Effects?. Bulletin for International Taxation, 71(12).

Hakelberg, L. (2015). The power politics of international tax co-operation: Luxembourg, Austria and the automatic exchange of information. Journal of european public policy, 22(3), 409-428.

Hasim, M. P., Priyono, F. J., \& Sa'adah, N. (2018). Karakter Multilateral Competent Authority Agreement On Automatic Exchange Of Financial Account Information Dan Implikasinya Pasca Program Tax Amnesty Di Indonesia. Diponegoro Law Journal, 7(4), 345-363.

Huang, X. (2018). Ensuring taxpayer rights in the era of automatic exchange of information: EU data protection rules and cases. Intertax, 46(3), 225-239.

Irianto, B. S., Sudibyo, Y. A., \& Wafirli, A. (2017). The influence of profitability, leverage, firm size and capital intensity towards tax avoidance. International Journal of Accounting and Taxation, 5(2), 33-41. 
Krustiyati, J. A., \& Hugeng, D. (2019, March). Obligations for Indonesian Banks to Report Its Customers Data to Tax Office Under Automatic Exchange of Information (AEOI) Stipulations. In Social and Humaniora Research Symposium (SoRes 2018) (pp. 594-596). Atlantis Press.

Lesage, D., Lips, W., \& Vermeiren, M. (2020). The BRICs and International Tax Governance: The case of automatic exchange of information. New political economy, 25(5), 715-733.

Petres, B. Z. (2020). Advanced Tax Rulings (I). Introductory Notions regarding the Tax Ruling, Some Considerations about Its Position in a European Taxation. A Comparative Analysis of the Ruling Procedure. Cluj Tax FJ, 36, 1-15.

Pratama, A. (2018). Individual taxpayer characteristics and taxpayer knowledge: exploratory survey on individual taxpayers in Bandung city, Indonesia. Review of Integrative Business and Economics Research, 7, 338-349.

Rahimi-Laridjani, E., \& Hauser, E. (2016). The new global FATCA: an overview of the OECD's common reporting standard in relation to FATCA. The International Tax Journal, 42(1), 31-38.

Rahmayati, R. (2021). Competition Strategy in The Islamic Banking Industry: An Empirical Review. International Journal of Business, Economics, And Social Development, 2(2), 65-71.

Setiawan, S. (2020). Third Party Funds and Non-Performing Financing for Mudharabah Financing in Indonesia's Sharia Banking. International Journal of Business, Economics, and Social Development, 1(4), 178-184.

Subagyono, B. S. A., Hernoko, A. Y., \& Chumaida, Z. V. (2019). A Comparative Study on Automatic Financial Exchange between Indonesia and Malaysia. Rechtsidee, 6(1), 10-21070.

Subroto, G. (2020). Knowledge management in Tax Administration: A Case Study in Indonesia. Scientax, 1(2), $203-235$.

Tedja, A. A., Wijaya, V. A., \& Lidyawati, J. (2019). Automatic Exchange of Information on Indonesia Jurisdiction in order to Control Business Opportunities. Notaire, 2(2), 143-156.

Wijayanti, A. (2019). Juridism Implementation Law Number 9 of 2017 as a Indonesian Commitment in Automatic Exchange of Information. International Journal of Civil Engineering and Technology (IJCIET), 10(5), 1156-1165. 